\title{
How Immigration Law Impacts the Household Life of F-2 Wives in the USA
}

\section{Samit Dipon Bordoloi}

Department of Health and Community Studies, Western Washington University, Bellingham, USA

Email: samit.bordoloi@wwu.edu

How to cite this paper: Bordoloi, S.D. (2016) How Immigration Law Impacts the Household Life of F-2 Wives in the USA. Open Journal of Social Sciences, 4, 111-129. http://dx.doi.org/10.4236/jss.2016.410009

Received: September 16, 2016

Accepted: October 23, 2016

Published: October 26, 2016

Copyright (@) 2016 by author and Scientific Research Publishing Inc. This work is licensed under the Creative Commons Attribution International License (CC BY 4.0).

http://creativecommons.org/licenses/by/4.0/

\begin{abstract}
This paper utilizes a feminist framework to examine the impact of immigration policies on the family and household life of wives of international students. The research process included interviews with thirty-two wives who came to the US on a F-2 visa, along with analysis of immigration policies. Immigration regulations, which prohibit wives from accessing full-time education and employment opportunities, reinforce traditional gender identities within the family. Migration is associated with a loss of power and unequal status within the marital relationship. F-2 wives report a significant increase in their burden of unpaid reproductive labor. The findings of this study contribute to the growing body of literature on how the migration of families to the United States is shaped by gendered institutions.
\end{abstract}

\section{Keywords}

Gender, Wives, International Students, F-2 Visa, Migration, Reproductive Labor

\section{Introduction}

International students are an integral part of the American higher educational system in the $21^{\text {st }}$ century. While there has been considerable focus on the adjustment challenges that international students face living in the United States, there has been little attention paid to the problems faced by their accompanying family members. International students are viewed as extremely valuable to American educational institutions because they add diversity in the classroom, as well as support teaching and research in programs that have the greatest need, such as the sciences (Johnson, 2003) [1] and contribute nearly 30 billion dollars to the economy (IIE, 2015) [2]. Although international students are accompanied by a growing number of spouses, the research literature has rarely focused on the experiences of these individuals (Martens \& Grant, 2008) [3]. As a 
result little is known about how the migration process impacts the development of gender relations within families of international students.

\subsection{Background of Problem}

Understanding the experiences of spouses of international students' requires researchers to acknowledge the gendered nature of the issue. In official documents the gender-neutral term "spouse" is used when referring to married partners of international students. However, the limited research on spouses of international students has identified this population as overwhelmingly female (Martens \& Grant, 2008) [3]. The majority of international graduate students (who are more likely to be married) are male (IIE, 2015) [2]. Immigration scholarship has shown that husbands are less likely to follow wives as dependents to another country due to the patriarchal organization of families in most societies (Pessar, 1999 [4]; Purkayastha, 2005 [5]). Given these factors one can infer that the majority of spouses of international students would tend to be female.

The majority of international students arrive in the United States on an F-1 visa, which is assigned for the specific purpose of higher educational study (IIE, 2015) [2]. Spouses of F-1 students are allowed to accompany themon a F-2 visa if they can document a legal marriage. Spouses on a F-2 visa are unable to seek work or enroll as full-time degree-seeking students and can only engage in recreational or voluntary activities outside of the home (Kim, 2006) [6]. They also cannot obtain a social security number, which is required to engage in any legal employment and most financial transactions in the United States. Due to these restrictions for spouses' of international students their stay in the United States is entirely contingent on their partner's academic plans and career aspirations.

There has also been little tracking of such spouses within the immigration system. For example, the Student and Exchange Visitor Information System (SEVIS) noted that as of July 2016 there were 152,553 student dependents in the United States (SEVP Quarterly Review, 2016) [7]. Unfortunately, the SEVIS system does not differentiate between adult spouses and dependent children when it comes to identifying F-2 student dependents, thus making it difficult to calculate the actual number of F-2 spouses. The publicly available SEVIS data also do not provide a gender break-up of the F-2 student dependents.

\subsection{Literature Review}

Given the limited research on the experiences of wives of international students it is useful to consider some of the research that has been conducted with other expatriate spouses, such as wives of business people and highly skilled professionals assigned to work abroad. While business and skilled professionals can find continuity in their work life, their spouses have limited access to organizational structures and may experience strong disruption of their personal lives (Ali, Van der Zee, \& Sanders, 2003) [8]. Copeland \& Norell (2002) [9] noted that the disruption of established social networks is particularly stressful for spouses as they face competing family responsibilities, social 
isolation, sociopolitical constraints, and changes in their social and/or work status. Suh and Lee (2006) [10] found that spouses experienced stress from language barriers, cultural adaptation, homesickness, financial difficulties, disrupted family relationships, and lowered self-esteem.

A key element in the migration of highly skilled workers is the gendered impact on household and work lives of women. According to Hardill \& MacDonald (1998) [11] such migration is particularly difficult for dual-career households; it could have a detrimental effect on the career of the other partner and disrupt family life. Moreover, they concluded that "one career (more frequently that of the woman) having to bear the burden of compromise in most instances" (p. 25). Purkayastha (2005) [5] described this process as one where professional women find that they have to make the "rational" decision to sacrifice their own career for the "household" interest. Meares (2010) [12] found that highly skilled women migrate due to familial motivations encounter "decreases in income and damaged career prospects... under-or unemployment. The impact on professional womens home lives ranges from an increase in household responsibilities and/or childcare to a complete immersion in the domestic sphere." (p. 475). Although wives of international students find themselves in a similar situation there has been very little scholarship that has examined the gendered impact of migration on their family life.

The current research literature has rarely focused on how immigration regulations that put F-2 visa holders in a dependent status, impacts their adjustment within American society. There have been virtually no studies that have looked at the impact of such regulations on the family dynamics and/or household structure of international students. A few studies, while not directly focused on the impact of immigration regulations, have discussed how wives of international students have found their lives impacted by such restrictions.

De Vertheyli (1995) [13] carried out an exploratory research of the adjustment experiences of 49 wives of graduate students in Virginia. She discovered that the majority ofwives had been employed full time in their home country and "arriving in the United States on a visa with work restrictions meant changing from an active professional life in the public sphere to a more traditional feminine role as a homemaker" (p. 398). Cho, Lee and Jezewski (2005) [14] in their study of 14 Korean wives of international graduate students reported that most of them struggled with economic hardship and a sense of low self-achievement due to their inability to pursue employment opportunities. Sakamoto (2006) [15] in her sample of 10 wives of Japanese scholars and students found that the change in status from being a working professional to becoming a full-time housewife led to even more pronounced gender roles than back in Japan. Chen (2009) [16] reported that wives of international students were often unhappy with their singular status as a housewife and wanted to return to the workplace. Teshome \& Osei-Kofi (2011) [17] in a sample of 12 female spouses found that due to immigration restrictions "their prescribed primary roles as homemakers are far removed from their previous lives, causing great dissonance.” (p. 9). 
The primary limitation in the above-mentioned studies is that none of them directly examine how immigration laws place structural barriers in the lives of F-2 visa holders. For example, while De Vertheyli's study (1995) [13] listed loss of professional identity due to restrictive visa status as a key finding, it did not question the gendered impact of such regulations. Rather she identified gender-role orientation i.e. "degree of acceptance, or rejection of the more traditional role as a homemaker (and mother) during the stay" (p. 404) as the key variable in the successful adjustment process. The problem with such a framework is that it situates the burden of coping/adjusting on the individual rather than questioning institutional policies that marginalize this population.

Kim (2006 [6], 2010 [18]) has been one of the few scholars who have looked at the direct impact of immigration regulations on the family life of international students. In her study of 11 Korean F-2 wives she concluded that by depriving them of educational and employment opportunities, immigration law compelled such women to engage only in unpaid care-work. According to her such regulations reflect a hetero-patriarchal ideology that enforces a nuclear family structure with a male breadwinner and female homemaker, maintaining and reproducing unequal gender relations. This study expands on Kim's (2006 [6], 2010 [18]) findings by looking at the experiences of women from 13 countries and multiple transitions they undergo in their family life due to immigration regulations. An understanding of the gendered impacts of migration on the family life of wives of international students is an important first step in the development of gender sensitive policies that better facilitate their integration into American society.

\subsection{Theoretical Framework}

This paper is based on the central themes that have defined feminist scholarship in family studies (Ferree, 2010 [19]; Thompson \& Walker, 1995 [20]). Such scholarship first and foremost emphasizes the centrality and value of women's experiences within families. Although there has been considerable research on the experiences of male international students, the experiences of their wives have been documented far less often, even forgotten. This paper seeks to bring to the forefront the previously marginalized voices of F-2 wives. Second, a feminist perspective recognizes gender as a social construct and that gendering activities at the individual level are situated in larger structures that have their own institutionalized gender practices and meanings (Martin, 2003) [21]. This paper illuminates how institutionalized gender practices at the level of immigration policy impact micro-level gendered activities within families of international students, such as household labor, parenting and income generation.

The third element of a feminist family studies framework is that it seeks to analyze gender relations not just within individual and interpersonal contexts but keeping in mind social and structural contexts. The family experiences of F-2 wives are located within an oppressive structural context that is defined by the nature of immigration processes, which like other social institutions although purport to be gender neutral, are not responsive to the interests and needs of women (Thompson \& Walker, 1995) 
[20]. Fourth, this paper demonstrates that gender as a social institution is an integral part of the state and is influenced by state policy (Ferree, 2010) [19]. Martin (2003) [21] points out that states have the power to create and implement laws that "...both reflect and create gender inequality when they lend state authority to gender institution practices by assigning women to an inferior status" (pp. 1258-1259). The immigration practices of the state, which prohibit F-2 wives from seeking opportunities outside the house, reflect a traditional gender ideology "that contains class, cultural and heterosexual biases and supports the oppression of women" (Osmond \& Thorne, 1993, pp. 593) [22].

\section{Method}

\subsection{Sample}

In this study the wife of an international student was defined as an individual who was living in the United States on an F-2 visa. Spouses of international students who were American citizens or students on an independent visa were excluded, as their visa status did not restrict their activities. The sample consisted of 32 F-2 wives drawn from 5 different institutions. To identify potential participants family members of international students were contacted through university and community listservs, mailing lists etc. Purposive and snowball sampling techniques were used to identify potential participants. A maximum variation sampling strategy was employed to identify and interview participants from multiple backgrounds, life-stages and different stages of stay. A semi-structured interview guide was used for the interviews, which allowed for greater exploration of particular issues according to the participant's social context. Participants received fifteen dollars to assist with any incidental costs related to participating in the interview (e.g., travel and food). The interviews lasted an average of 60 minutes and were audiotaped. All the procedures outlined in the study were reviewed and approved by the appropriate Institutional Review Boards. Participants in this study came from thirteen different countries. The majority of participants were between the ages of twenty-five to thirty-five. The length of marriage spanned from less than a year to ten years and most of the participants had been in the United States for one to three years. At the time of the interview three of the participants were pregnant and six had one or more children. Only one participant had a child while living in the United States. All the participants in the study were highly educated, only two of the thirty-two participants did not have a college degree and both of them had completed an associate degree from their native country. The F-2 wives in this study had a wide range of educational experiences, from architecture and engineering to psychology and law. A number of participants were from a Science, Technology, Engineering and Mathematics (STEM) background and two of the participants had acquired graduate/professional degrees from other countries.

\subsection{Research Strategy}

The findings in this paper are have been developed with the framework of Institutional 
Ethnography (IE), a feminist research strategy developed by Dorothy Smith (1987) [23]. IE as a research framework is useful to identify how everyday experience is socially organized. Institutional ethnographers seek to uncover how or dinary life processes at the local level are coordinated by extra-local proceedings, which are often beyond the scope of everyday interaction. As De Vault and McCoy (2002) [24] noted, IE allows for 'the empirical investigation of linkages among local settings of everyday life, organizations, and translocal processes of administration" (p. 751). For example, the daily family life of F-2 wives is often coordinated and organized by immigration policies that are not necessarily visible during regular interaction. IE as an alternative method of inquiry is fruitful for studies that focus on marginalized voices and neglected topics; as such matters directly challenge ruling forms of social organization and mainstream discourses (Grahame, 2003) [25]. IE offers a methodological tool that is ideal for researching how immigration regulations influence the family relationships and household life of wives of international students.

In this study F-2 wives and their everyday experiences is the point of entry in analyzing how the institutional organization of immigration coordinates their family life. As a feminist epistemology this IE places F-2 wives at the center of the research process. The goal of such a standpoint is to ensure that "concrete experiences provide the starting point from which to build knowledge" (Hesse-Biber \& Leavy, 2007, p. 56) [26]. An analysis of entry-level data leads the institutional ethnographer to second level data, such as texts and policies (Campbell \& Gregor, 2004) [27].

According to Smith (1987) [23] IE as a methodology allows the researcher to move from "a woman's account of her everyday experience to exploring from that perspective the generalizing and generalized relations in which each individual's everyday world is embedded" (p. 185). Nichols and Griffith (2009) [28] noted that in IE research participants are not the objects of analysis, rather, their accounts are used to provide an analytic point of entry into the complex of institutional relations that coordinate their lives. Therefore, institutional ethnography works with data differently than traditional qualitative research methodologies. When interviewing participants, the focus is on the informants' everyday experience. However, the research focus does not linger there, rather it seeks to locate how an individual's experience is coordinated by the institutional relations with which they engage. At this point in the research institutional ethnographers begin to examine texts. In this study "texts" included government regulations, immigration laws, official documents and university policies that are associated with the F-2 visa process.

Examining texts allow the institutional ethnographer to make visible how institutional processes shape the lives of the research participants. For example, participants in this study shared that their burden of household and reproductive labor increased once they arrived in the United States. A subjective analysis of interview data would have focused only on gendered within-family relationships. However, IE allowed the researcher to analyze "texts" to identify linkages between family dynamics and institutional relationships that limit the options for F-2 wives outside the household. 


\subsection{Data Analysis}

Interviews with all respondents were transcribed verbatim. All the data, which included transcripts and various "texts", was grouped together based on theme or topic. The data was organized using both "literal" and "focused" coding (Hesse-Biber, 2007, p. 334). p. 334) [26]. Literal coding involves using words that appear within the transcripts or documents and are predominantly descriptive in nature (Hesse-Biber \& Leavy, 2010) [29]. The next step was creating a focused code procedure and list of analytical categories. As Hesse-Biber \& Leavy (2010) [29] noted, "focused coding procedure allows for the building and clarifying of concepts" and it allows the researcher to "develop more abstract code categories from which one can generate theoretical constructs" (p. 311). For example, in the case of this study moving from identifying words/phrases such as "no money", "loss of income" and "ask my husband for money" from the participants narratives to creating the construct of "loss of financial independence" as it related to F-2 wives. Memoing was used as a tool to "elaborate processes, assumptions and actions" (Charmaz, 1995, p. 42) [30] and categorize the data rooted in the codes. ATLAS/ ti, a qualitative data analysis software program, was used to manage all the data and organize and identify key linkages between the different levels of data.

\subsection{Limitations}

It is important to acknowledge the limitations inherent in this research study. Since the entire research was carried out in English, it does not include the experiences of individuals who were unable to speak the language, potentially a population that is most vulnerable to oppression. Since the research design primarily used university resources (such as listservs) to reach out to study participants; it was difficult to reach individuals who were not connected with the university. Due to the nature of snowball sampling, it is possible that some of the sample was drawn from familiar social networks. The researcher is a male of Indian origin who interviewed wives of international students from various cultures about their personal and marital experiences. Due to gender and cultural differences some of the participants may not have shared relevant details about their experience.

\section{Findings}

\subsection{Dependent Status}

The immediate impact of immigration regulations is that when an F-2 wife arrives in the United States she finds herself legally dependent on her husband. Under immigration law wives of international students are considered "dependents" of the primary visa holder, the F-1 international student. F-2 wives do not have independent immigration status in the United States and their presence is entirely contingent upon their husband. Shi Chuo noted that the documents that she carried reflected this dependency. In China she was a successful professional, the vice-president of a company, but in the US her identity was derived completely from her husband's status. Shi Chuo de- 
scribed her embarrassment every time she had to show her identification, "if you want to show your identification you need all his identification with you. When you show your passport you need to show his also because you have the visa, your visa is a spouse of F-1 visa".

Due to his status as the primary visa holder the husband tends to wield considerable power within the marital relationship and F-2 wives have to depend on their husband's goodwill to maintain their presence in the United States. Such legal dependency on the husband gives a F-2 wife almost no options if he is not supportive of her attempts to access opportunities outside the household. For example, if a F-2 wife wants to change to an employment visa or student visa she needs her husband to provide his F-1 visa and supporting documents to prove that her presence in the United States is legal and valid. Studies with other immigrant groups show that women who arrive in the United States through the route of marriage, due to their legal dependency on their husband, face barriers to integration and are vulnerable to spousal abuse (Dasgupta, 2000) [31].

Chitra was working as an executive manager in India when her marriage was arranged with an Indian international student who was in the USA. She had hoped that he would help her transfer to a work permit or enroll in a course of study in the USA. She noted that due to her legal status as a dependent there was little she could do without the approval of her husband.

I wanted to do masters degree. He said you know you'll never be able to ...here my decisions are based on his decisions because I'm totally dependent on him for everything. I'm dependent on him for even a single money, for every single thing. Even if I have to go out I'm dependent on him... whatever he has to take the decision I have to abide on it.

A number of other respondents expressed concerns about the impact of such dependency on their marital relationship. The key concern was that the dependency consigned the wife to unequal status within the martial relationship. Chou said that she tried to keep her husband in good humor to ensure that she is able go about pursuing her interests, "I have to pretending to be very sweet, if he gets angry, he will say no he couldn't (support me)."

\subsection{Loss of Financial Independence}

F-2 wives find that their financial status and standard of living are often reduced as a result of their migration to the USA (Martens \& Grant, 2008) [3]. Since the overwhelming majority of F-2 wives in this study were employed full-time in their home country, they found their situation dramatically different in the USA. While this reduction in family income can create additional problems in adjustment (De Verthelyi, 1995) [13], a number of F-2 wives shared that they primarily struggled with the loss of financial independence. Virina had a successful career as an art curator in Mexico and had been financially independent for more than a decade. When she arrived in the US she described the loss of independent income as a feeling of powerlessness. 
I had less power over things you know, I cannot decide basically. (In Mexico) we were kind of really open about money issues. So let's say I went somewhere and I like shopping, I have my money I say oh I'll buy it no worries. I can't do that here because I don't have it. Yeah it's pretty tough.

For F-2 wives who had been working full-time the loss of income was associated with financial dependency on the husband, which was not compatible with their self-identity of an independent woman.

Shohreh: I used to have a good income in Iran. I had my independent salary. It's really great to have something for your own that you can spend it anyway you want. But here anything I want I have to tell my husband. Okay can you pay for this? It's hard for me, it's hard. I want to have my independence and I cannot have it without having a personal income.

A number of respondents pointed out that the loss of financial independence changes the dynamic within the couple relationship. Financial dependence on their husband meant that F-2 wives had to constantly ask their husband for money. As Alejendra noted, it was particularly uncomfortable when it came to personal expenses, "I want to have my hair cut please its fifty-five dollars. Can I spend that amount of money having my hair cut? And my husband always says sure, but I have to ask before."

For F-2 wives the financial dependency on their husband was not just a "private" family matter but constructed and supported by various regulations. The key issue is that F-2 wives are not assigned a social security or tax identification number and cannot carry out even simple financial transactions, such as having their own bank account or credit card. Therefore, such regulations fundamentally alter the manner in which couples negotiate financial issues within their relationship. Chen Yi pointed out that although she had savings back home, to access the money she had to go through her husband, since the bank account in the US was in his name.

I still have my own money here but that I spend is dependent on my husband and he pays it all and he give me some... makes me uncomfortable because just like I have to (ask) approval to take the money

Cao Zhou noted that even carrying out everyday purchases on her own is difficult and often embarrassing "because I don't have credit card so only my husband have and if I use his credit card they will ask me to let him to sign. So I felt oh not good, I don't have independent life."

Such structural dependency could create scenarios where the husband limited the wife's mobility by withholding access to financial resources. Chitra wanted to take driver education classes and apply for a driver's license so that she would have greater mobility outside the household. However, her husband prohibited her from enrolling in the class, as he deemed it too expensive.

So he said "you don't have to take the license because it's that much fees". So

"whenever we'll go somewhere outside we'll get your driver license because won't 
be that much fees and the course won't be mandatory". And "why do you want to drive here so soon?" So all those things I have to be dependent on him he's the one who's paying for me.

\subsection{Household Labor}

F-2 wives in this study reported a significant increase in their level of participation in housework. Feminist scholars have extensively studied the role of gender in the performance of housework and have argued that the allocation of the primary responsibility for housework to women is the key to the reproduction of gendered traditionalism (West and Zimmerman, 1987) [32]. Although due to societal changes there is increased participation by men, women still do the majority of the housework (Hertz, 2011) [33].

Taking on an unequal burden of household work was not necessarily a new situation for a number of the F-2 wives. They acknowledged that in their home country the burden of household work traditionally fell on the wife. Wives who had a professional career often found that they were stuck with the "second shift" (Hochschild, 1989) [34]; they did the bulk of household work and childcare after their paid workday was done. At best, a few participants reported, their husband contributed to the household labor on an irregular basis. However, since most of the participants were dual-earner couples in their home country they could afford to hire domestic help. They also got help from other family members, particularly parents on both sides of the family.

After they arrived in the USA F-2 wives found themselves without the support of family members. Their only source of income was their husbands' research/teaching stipend (if he had one), which barely covered the needs of two people. Without the income of the wife the couple could not afford to hire outside help for housework or childcare. Therefore, the burden of housework that was anyway skewed towards the wife, increased dramatically.

Seung described the initial months of living in the US as a stressful time where she had to juggle the dual responsibilities of being a housewife and a mother without any support. As a working professional in South Korea, it was a task she was ill prepared for, "here I was the only one who has to clean the house, cook the meals and take care of my son. So I was very stressed out all day." Similarly in India Ayesha had domestic help that took care of most household chores while she focused on taking care of her son and her career as a freelance writer.

Mostly it's the pressure of actually being over here and expected to do everything on my own... its hard just being by yourself all day long being expected to do every single thing, kind of from paying bills from going to the shop (and) buying milk.

Some F-2 wives acknowledged that their husbands were more likely to help them with household work than back in their own country. However, rather than taking on a more equal share the role of the husband was still that of a helper. Helper husbands often wait to be told what and how to do tasks in household rather than taking primary responsibility (Coltrane, 1989) [35]. F-2 wives find that asking their husbands to con- 
tribute more to domestic and family responsibilities is complicated by their unequal status outside the boundaries of the household. When examining the unequal division of household labor within the families of international students, there are two factors in play-the role of income and availability of time, both of which are impacted by immigration regulations.

\subsection{Role of Income}

Family studies scholars have used the relative resource model to argue that the allocation of household labor is generally on the basis of economic exchange (see Erickson, 2005) [36]. The partner who brings more resources to the marital relationship is able to use these resources to "buy out" of the performance of household labor. Due to the historical disparity in income men are more likely to be able to buy out of performing household labor. Feminist scholars have criticized this model by showing that women who have professional careers and are on equal footing in terms of income are still responsible for the bulk of household work and child care after their paid work day is done (Hochschild, 1989 [34]; Grahame, 2003 [25]). This is also reflected in the narratives of most F-2 wives who note that they had an unequal burden of housework even when they were working. However, in their home country, as working professionals, wives were able to use their income to transfer the responsibility of household labor to other individuals.

When they arrive in the USA F-2 wives no longer have the option of contracting out household labor. However, since the husband still brings in more resources, relative to the wife, he is able to "buy out" of housework. Even if the husband is not employed, his engagement in education is seen as more economically valuable than the wife's contribution to housework. Therefore, the F-2 wife finds herself more involved in housework than her husband. Some participants did not necessarily see this increase in household labor as unfair. Yan, who is from China, acknowledged that the burden of housework is skewed towards her "I do more housework, yeah he do less housework but he do more research and work outside." Cao Zhou, who had a full-time job as a business professional in China, gave a similar justification about the increase in her share of the household labor "I think I do more housework than he... from this point I should understand him and do something for him because anyway he is income making source for our family." Virina acknowledged that she and her husband shared all the housework back in Mexico, however, after arriving in the US her share had increased.

Because now I don't work... here I feel I've decided to help with that part (housework) while he was at school. Well we never talk about it, but I just take charge of that because it felt I wanted to do it and he was really comfortable with that getting back from long days at school having dinner so it was kind of like a non spoken agreement.

It is interesting to note that the increase in housework took place in an implicit manner rather than through an overt acknowledgment. Some F-2 wives saw taking on 
the burden of household labor as being supportive of their husband's endeavors to better the family.

However, the increased burden of housework on F-2 wives is not a reflection of couple dynamics but a result of structural conditions that place these women at a disadvantage. The root of the unequal division of household labor lies in the immigration regulations that restrict F-2 wives from seeking employment and/or educational opportunities. F-2 wives do not have the option of accessing resources outside the household to "buy out" of household labor and/or transfer domestic responsibilities to other caretakers. Darya acknowledged the unfair aspect of such division of household labor. She identified the loss of financial independence as the primary influence in the unequal distribution of household labor. Since she was not involved in any "productive" economic activity she has little choice but to help the family unit by taking on the burden of domestic responsibilities.

I thought more things should be equal between two people. But I could never imagine that I live with someone without having my own income... But I think I got used to, not used, but I accepted it.... I can say that I do more (housework) than in Iran... when I know that he is working 10 hours a day 12 hours a day I think that this is the least that I can do.

\subsection{Availability of Time}

The time constraints approach theorizes that marital partners performance of household labor is negatively related to their time spent in paid employment (see Erickson, 2005) [36]. Both husbands and wives "are expected to perform family work to the extent that other demands on their time allow them to do so" (Erickson, 2005, p. 339) [36]. A number of participants cited their husband being "busy" with academic and work responsibilities as the primary reason for the unequal division of household labor. Some of the participants tried to arrange a more equitable division of household labor with their husbands. However, they often find that the husband's contribution is irregular and, more importantly, unreliable. Invariably, wives found that they would have to pick up the slack and be responsible for the bulk of the housework. Aakanksha said that an equitable arrangement was not workable, "like at weekdays I can never say to him because he comes home at 9 PM. Okay I cannot say to him wash the utensils, so whatever (he can) he does." Noelie shared that she and her husband tried to come up with a schedule for sharing household tasks, however, she found herself often taking on his share.

For example, cleaning the house in my mind it would be a team like okay, you clean the bathroom every week and I will do the dishes and the laundry. And we tried at the beginning but it's really difficult for him to do that because he is studying. And if I see him studying until 3 AM I don't have the heart to tell him you didn't clean the bathroom or didn't do the dishes. So in that sense I'm very supportive. 
Applying a gender lens to the time constraints approach shows that the F-2 wife's inability to access paid employment or educational opportunities means that she was less "busy" than her husband. As a consequence she was perceived to have more "time" to engage in household labor. On the other hand the husband got to opt out of his share since he was "busy" with outside activities.

Alejendra's narrative illustrated the role of "time" in the unfair division of labor in her household. She was expected to carry out household tasks, even the ones she disliked, because she was not working, while her husband got to opt out because of his academic responsibilities. She used the example of ironing to illustrate this disparity, "I don't like ironing but I have to do it because you (husband) can't do it and I can do it because I have a lot of time free. But I hate ironing, it's not fair".

\subsection{Impact on Career Prospects}

Beyond the unfair division of labor, the key point of concern for most participants was that the work within the household had no economic value. Although participants recognized that their labor contributed to the good of the family it did little to enhance their career prospects. Parvati contrasted her life as a successful designer in India with her status as a housewife in the US. Prior to coming to the US she had never bothered with housework, while here her daily life revolved around cleaning and cooking, skills that did not translate well into the professional world. While describing her future employment prospects she sarcastically pointed out "I feel now I am perfect in some servant kind of employment".

Ayesha acknowledged that while her contribution was valuable to her family, the outside world did not view it as economically productive. Her involvement in unpaid housework meant that she could not focus on her freelance writing, which unlike housework provided her with economic benefits.

What I am doing is of value. It's value in terms of what I'm contributing to the family so it doesn't' have a monetary value, but it does have a lot of worth attached to what I'm doing. But at the same point of time it's very hard to translate that worth into financial terms.

Feminist scholars have emphasized the need to view the household labor performed by women, such as cleaning, cooking and raising children as work that is economically productive since such labor "maintained workers and produced future workers engaged in wage labor, in effect making capitalist production possible” (Garey \& Hansen, 2011, p. 3) [37]. However, F-2 wives recognized that their household work on behalf of their families held little value outside the domestic sphere.

F-2 wives with previously successful professional careers said that they were not interested in keeping a "good" house and never saw their primary identity as that of a housewife. They were particularly concerned that such an arrangement would consign them to a permanent status as a dependent housewife.

Shohreh: One of the major concerns how much I put time for just housekeeping 
things you know. Baking, cooking, cleaning, I personally don't think that's a very gorgeous life. To just spend your days at home watching TV all those female shows and then cooking different foods, recipes. Cleaning all the time just to have a shiny house... And just spending all my life at home after because life passes so quickly and after 20 years, 10 years I end up being a middle age woman doing nothing.

\subsection{Reifying Patriarchy}

One could argue the patriarchal organization of the family system for most participants was also influenced by the husband's pre-migration gender beliefs. However, it is important to keep in mind in their home countries the overwhelming majority of F-2 wives had independent professional careers. Most of the participants noted that in their home countries they had access to social and financial resources outside the household. Therefore, in the US immigration policies that prevent wives from working or studying reified a patriarchal household that constricted women to the realm of reproductive labor. Such unpaid labor tended to subsidize men's "productive" activities outside the house (Kim, 2010) [18]. Over time within the family of international students such an unequal division of labor came to be seen as "natural". It was easy to accept the rationalization that since the husband is "working" outside the house and the wife "stays" at home, the unequal burden of domestic responsibilities was not unfair.

Although she was comfortable in her role as a housewife, Yan seemed to have an intuitive understanding of the gendered and patriarchal nature of such immigration regulations.

You see an international student is special. (The) $\mathrm{PhD}$ workload is hard also. So when wife comes here it's their work. No one to take care of their house it's impossible so their house becomes dirty. Its not good to their family relationship... as a woman sometimes family is more important so just stability of a family maybe sometimes is more important than your work. Because you can start your work every time you want. But if the relationship of family breaks (it) is hard to get it back together. So I think it's (immigration regulations) there to be a housewife.

One could argue that such an arrangement could conceivably work for a couple with traditional gender role orientation. However, for most participants the role of a housewife, whose only job was to support her husband, was not a familiar one. Alejendra pointed out that when she was in Argentina she had the same rights as her husband. She was working as a training manager with a multinational consulting firm and had built an identity as a successful professional. While all her life she had seen herself as an equal to her husband, it was US immigration law that assigned her to a secondary status, "I feel like I'm a side effect, like collateral effect. That my husband is here. Okay your wife can come with you. Be quiet, don't do that, don't do anything. It is unfair, it's like why I cannot work?"

\subsection{Motherhood}

A key finding was that for F-2 wives motherhood was strongly influenced by the re- 
strictive nature of immigration regulations. Out of the thirty-two participants in the study five were either pregnant or had a child during their stay in the USA. A number of other participants shared that they were considering starting a family. Since motherhood, particularly in the initial years is a time-intensive process; some participants saw the inability to work or study as a "forced" break that would allow a focus on motherhood. Virnia acknowledged that being unable to work meant that she could focus on motherhood, "but definitely I kind of like thought it was the right time because I stopped and I was not doing anything else... we wanted to take advantage of being here in the sense of me having more time."

However, for others the decision to have a child seemed to be borne out of their frustrations with the lack of options outside the household. In contrast to other forms of household work, these participants frame motherhood and childcare as work that is "productive". Shen Jiu made the decision to have a baby after a year of attempting to find employment in the USA. She said that having an infant to take care of allowed her to feel useful "because I have a baby now, I feel better but I think if I don't have baby maybe I will feel upset often".

Xiang said that finding herself in a situation with little options outside the household she made the decision to become pregnant. She acknowledged that being pregnant ensured that she was not feeling frustrated by her lack of options outside the household.

After I (got) pregnant, I'm so happy everyday I think (about) the baby, so because this is my first baby I should do some research about the baby and feel the baby grow up day by day, so I (am) focused on the baby so I don't feel bored.

F-2 wives often struggled with the idea of motherhood and its impact on their own professional and educational aspirations. Cao Zhou said that while she often thought about having children, she was worried about the consequences, "But sometimes I am hesitating, because if I have a kid I think I don't have time to pursue my dreams."

Others expressed concerns about how the presence of a child might permanently consign them to the household sphere. Given the unequal burden of household labor, they were aware that having a child would only mean greater domestic responsibilities but also impact their personal happiness. Dang Kuo acknowledged that although motherhood was on her mind she was concerned about its long-term consequences.

Maybe two years later we have children (and) I have to take care of my children. And I saw some friends of mine my friend get married have baby and they look like very old woman and no smile I think so. Of course they smile, but I don't think they are really happy. So I don't want to be that.

Despite reservations most participants acknowledged that given the lack of opportunities outside the household at some point they would have to consider the option of starting a family. Shohreh, gave voice to this sentiment, "I don't know it depends on my situation but if I end up having no admission from nowhere and just want to stay at home then the chance will be I just have a child." Therefore, the inability to seek opportunities outside the household steered F-2 wives to what they perceived as the only 
"productive" option available within the confines of the home-motherhood.

\section{Discussion}

This study contributes to our understanding of how immigration processes impact men and women within families differently. In the case of international students since husbands and wives do not enter the immigration process equally, they experience migration differently. For F-2 wives the legal dependency on their husbands is accompanied by a loss of financial independence and unequal status within the marital relationship. The inability to access opportunities outside the household results in a significant increase in F-2 wives burden of unpaid reproductive labor. Such reproductive labor although valuable to the family, does little to enhance their professional skills or career prospects. F-2 wives were often forced to make an identity transition from being a professional career-oriented woman to that of a homemaker. The immigration regulations that prevent F-2 wives from seeking employment or full-time education are based on gendered constructions of family relationships that place the burden of preserving and caring for the family unit on women. By ensuring that F-2 wives are unable to seek opportunities outside the home, these regulations force them to take on the burden of unpaid family care work. Invariably, this frees the husband to contribute to the higher education economy without having to worry about domestic responsibilities.

The process of migration to another country can be an extremely difficult experience and "can produce profound psychological distress among the most motivated and well prepared individuals, and even in most receptive circumstances" (Rumbaut, 1991, p. 56) [38]. The findings of this study show that for F-2 wives the organization of immigration regulations produce a uniquely dissonant immigrant experience. The restrictions on employment and education prevent the very thing that F-2 wives would like to do integrate better within American society. As Kim (2010) [18] noted, such restrictions are designed to discourage international students and their families from staying beyond the duration of their study. However, research has shown that such restrictions do little to discourage international students from staying on in the United States after completing their education. One comprehensive study found that forty-five percent of international students plan to work in the USA for at least a few years and fifteen percent plan to stay permanently (Policy Implications, 2005) [39]. Similarly, Finn (2003) [40] discovered that nearly seventy-one percent of foreign-born doctorates in the United States planned to stay on after graduation. Close to half of the participants in this study shared their husbands, after graduation, planned to seek jobs in the United States and stay on at least for a few years, if not permanently.

Therefore, the impact of such restrictions on international students' intent to stay in the USA is debatable. However, they tend to have an unequal impact on wives on a F-2 visa. While international students can integrate, gain new skills and even develop strong ties through their education, wives on F-2 visa are denied such opportunities. Upon graduating international students can seek out employment opportunities that allow them obtain a work permit and move towards permanent residency. Over the same 
time period wives on an F-2 visa find that their skill sets have regressed and they are locked out of the job market for an extended duration. F-2 wives find their family life is shaped in a patriarchal manner, with their husbands working in the "public sphere" while they are consigned to the "private sphere" of household labor and carework. The practical impact of such restrictions is that it relegates wives of international students to a secondary status, both within their families and in the larger US society.

While this study has identified a number of structural barriers that impact the lives of F-2 wives, there is need for more research on multiple fronts. From a family studies perspective there is great need for scholars to examine and understand the impact of such a realignment of power within the family system. Immigration scholars have to question the current regulatory system that assigns certain individuals to dependent status and provides them with few rights and resources. Gender scholars can call attention to the role of the state in perpetuating a patriarchal social system, through a complex nexus of regulations and policies that marginalize the voices of women and assign them to an inferior status.

\section{References}

[1] Johnson, V. (2003) Unintended Consequences: Unilateral Disarmament in the Battle of Ideas, Values, and Beliefs. International Educator, 12, 2-5.

[2] Institute of International Education (IIE) (2015) Open Doors 2015 Report: Information and Data Tables. http://opendoors.iienetwork.org/

[3] Martens, V.P. and Grant, P.R. (2008) A Needs Assessment of International Students' Wives. Journal of Studies in International Education, 12, 56-75. http://dx.doi.org/10.1177/1028315306293547

[4] Pessar, P.R. (1999) Engendering Migration Studies: The Case of New Immigrants in the United States. American Behavioral Scientist, 42, 577-600. http://dx.doi.org/10.1177/00027649921954372

[5] Purkayastha, B. (2005) Skilled Migration and Cumulative Disadvantage: The Case of Highly Qualified Asian Indian Immigrant Women in the U.S. Geoforum, 36, 181-196. http://dx.doi.org/10.1016/j.geoforum.2003.11.006

[6] Kim, M. (2006) Forced into Unpaid Carework: International Students' Wives in the United States. In: Zimmerman, M.K., Litt, J.S. and Bose, C.E., Eds., Global Dimensions of Gender and Carework, Stanford Social Sciences, Stanford, 162-176.

[7] SEVP (2016) SEVIS by the Numbers: General Summary Quarterly Review. https://www.ice.gov/sites/default/files/documents/Report/2016/sevis-bythenumbers-0416.pdf

[8] Ali, A.J., Van der Zee, K.I. and Sanders, G.J.E.M. (2003) Determinants of Intercultural Adjustment among Expatriate Spouses. International Journal of Intercultural Relations, 27, 563-580. http://dx.doi.org/10.1016/S0147-1767(03)00054-3

[9] Copeland, A.P. and Norell, S.K. (2002) Spousal Adjustment on International Assignments: The Role of Social Support. International Journal of Intercultural Relations, 26, 255-272. http://dx.doi.org/10.1016/S0147-1767(02)00003-2

[10] Suh, S. and Lee, M. (2006) Group Work for Korean Expatriate Women in the United States: An Exploratory Study. The Journal for Specialists in Group Work, 31, 353-369. http://dx.doi.org/10.1080/01933920600918949

[11] Hardill, I. and MacDonald, S. (1998) Choosing to Relocate: An Examination of the Impact 
of Expatriate Work on Dual Career Households. Women's Studies International Forum, 21, 21-39. http://dx.doi.org/10.1016/S0277-5395(97)00085-X

[12] Meares, C. (2010) A Fine Balance: Women, Work and Skilled Migration. Women's Studies International Forum, 33, 473-481. http://dx.doi.org/10.1016/j.wsif.2010.06.001

[13] De Verthelyi, R. (1995) International Students Spouses: Invisible Sojourners in the Culture Shock Literature. International Journal of Intercultural Relations, 19, 387-411. http://dx.doi.org/10.1016/0147-1767(95)00028-A

[14] Cho, K., Lee, J. and Jezewski, M.A. (2005) Korean Women Living in the United States as Student Wives. Health Care for Women International, 26, 897-915. http://dx.doi.org/10.1080/07399330500301838

[15] Sakamoto, I. (2006) When Family Enters the Picture: The Model of Cultural Negotiation and Gendered Experiences of Japanese Academic Sojourners in the United States. Cultural Diversity and Ethnic Minority Psychology Journal, 12, 558-577. http://dx.doi.org/10.1037/1099-9809.12.3.558

[16] Chen, L. (2009) Negotiating Identity between Career and Family Roles: A Study of International Graduate Students' Wives in the US. International Journal of Lifelong Education, 28, 211-226. http://dx.doi.org/10.1080/02601370902757075

[17] Teshome, Y. and Osei-Kofi, N. (2011) Critical Issues in International Education: Narratives of Spouses of International Students. Journal of Studies in International Education, 20, 113.

[18] Kim, M. (2010) Gender Politics and Global Householding in International Student/Scholar Families. Politics \& Gender, 6, 288-295. http://dx.doi.org/10.1017/S1743923X10000097

[19] Ferree, M.M. (2010) Filling the Glass: Gender Perspectives on Families. Journal of Marriage and Family, 72, 420-439. http://dx.doi.org/10.1111/j.1741-3737.2010.00711.x

[20] Thompson, L. and Walker, A. (1995) The Place of Feminism in Family Studies. Journal of Marriage and the Family, 57, 847-866. http://dx.doi.org/10.2307/353407

[21] Martin, P.Y. (2003) Gender as a Social Institution. Social Forces, 82, 1249-1274. http://dx.doi.org/10.1353/sof.2004.0081

[22] Osmond, M.W. and Thorne, B. (1993) Feminist Theories: The Social Construction of Gender in Families and Society. In: Boss, P.G., Doherty, W.J., LaRossa, R., Schumm, W.R. and Steinmetz, S.K., Eds., Sourcebook of Family Theories and Methods. A Contextual Approach, Plenum, New York, 591-625. http://dx.doi.org/10.1007/978-0-387-85764-0_23

[23] Smith, D.E. (1987) The Everyday World as Problematic: A Feminist Sociology. Northeastern University Press, Boston.

[24] DeVault, M. and McCoy, L. (2002) Institutional Ethnography: Using Interviews to Investigate Ruling Relations. In: Gubrium, J. and Holstein, J., Eds., Handbook of Interview Research: Context \& Method, Sage, Thousand Oaks, 751-776.

[25] Grahame, K.M. (2003) "For the Family": Asian Immigrant Women's Triple Day. Journal of Sociology and Social Welfare, 30, 65-90.

[26] Hesse-Biber, S.N. (2007) Putting It Together: Feminist Research Praxis. In: Hesse-Biber, S.N. and Leavy, P.L., Eds., Feminist Research Practice, Sage, Thousand Oaks, 329-349. http://dx.doi.org/10.4135/9781412984270.n11

[27] Campbell, M. and Gregor, F. (2004) Mapping Social Relations: A Primer in Doing Institutional Ethnography. Garamond Press, Toronto.

[28] Nichols, N. and Griffith, A.I. (2009) Talk, Texts, and Educational Action: An Institutional Ethnography of Policy in Practice. Cambridge Journal of Education, 39, 241-255. 
http://dx.doi.org/10.1080/03057640902902286

[29] Hesse-Biber, S.N. and Leavy, P. (2010) The Practice of Qualitative Research. Sage, Thousand Oaks.

[30] Charmaz, K. (1995) Grounded Theory. In: Smith, J., Harré, R. and Langenhove, L., Eds., Rethinking Methods in Psychology, Sage, London, 27-65.

http://dx.doi.org/10.4135/9781446221792.n3

[31] Dasgupta, S.D. (2000) Changing the Course: An Overview of Domestic Violence in the South Asian Community in the United States. Journal of Social Distress and the Homeless, 9, 173-185. http://dx.doi.org/10.1023/A:1009403917198

[32] West, C. and Zimmerman, D.H. (1987) Doing Gender. Gender and Society, 1, 125-151. http://dx.doi.org/10.1177/0891243287001002002

[33] Hertz, R. (2011) Why Can't I Have What I Want? Timing Employment, Marriage and Motherhood. In: Garey, A.I. and Hansen, K.V., Eds., At the Heart of Work and Family. Engaging the Ideas of Arlie Hochschild, Rutgers University Press, New Brunswick, 74-85.

[34] Hochschild, A.R. (1989) The Second Shift: Working Parents and the Revolution at Home. Viking, New York.

[35] Coltrane, S. (1989) Household Labor and the Routine Production of Gender. Social Problems, 36, 473-490. http://dx.doi.org/10.2307/3096813

[36] Erickson, R.J. (2005) Why Emotion Work Matters: Sex, Gender, and the Division of Household Labor. Journal of Marriage and Family, 67, 337-351. http://dx.doi.org/10.1111/j.0022-2445.2005.00120.x

[37] Garey, A.I. and Hansen, K.V. (2011) Introduction: An Eye on Emotion in the Study of Families and Work. In: Garey, A.I. and Hansen, K.V., Eds., At the Heart of Work and Family. Engaging the Ideas of Arlie Hochschild, Rutgers University Press, New Brunswick, 1-14.

[38] Rumbaut, R.G. (1991) Migration, Adaptation, and Mental Health: The Experience of Southeast Asian Refugees in the United States. In: Adelman, H., Ed., Refugee Policy: Canada and the United States, York Lanes Press, Toronto, 383-427.

[39] Policy Implications of International Graduate Students and Postdoctoral Scholars in the United States (2005) Board on Higher Education and Workforce, National Research Council. National Academies Press, Washington DC.

[40] Finn, M.G. (2003) Stay Rates of Foreign Doctorate Recipients from US Universities 2001. Oak Ridge Institute for Science and Education, Oak Ridge. 
Submit or recommend next manuscript to SCIRP and we will provide best service for you:

Accepting pre-submission inquiries through Email, Facebook, LinkedIn, Twitter, etc. A wide selection of journals (inclusive of 9 subjects, more than 200 journals)

Providing 24-hour high-quality service

User-friendly online submission system

Fair and swift peer-review system

Efficient typesetting and proofreading procedure

Display of the result of downloads and visits, as well as the number of cited articles

Maximum dissemination of your research work

Submit your manuscript at: http://papersubmission.scirp.org/

Or contact jss@scirp.org 